\title{
Assessment of Polycyclic Aromatic Hydrocarbons in Popularly Known Commercial Brands of Soft drinks Sold in different Cities in Nigeria
}

\author{
Verla Andrew Wirnkor ${ }^{1}$, Verla Evelyn Ngozi $^{2}$, Enyoh Christian Ebere ${ }^{{ }^{*}}$, Obidike Blessing Magrette ${ }^{1}$ \\ ${ }^{1}$ Group Research in Analytical Chemistry, Environment and Climate Change (GRACE\&CC), Department of \\ Chemistry, Imo State University Owerri, P. M. B 2000, Imo State, Nigeria \\ ${ }^{2}$ Department of Environmental Technology, School of Environmental Science, Federal University of \\ Technology, Owerri, P.M.B.1526, Imo State, Nigeria
}

*Corresponding Author: Enyoh Christian Ebere, Group Research in Analytical Chemistry, Environment and Climate Change (GRACE\&CC), Department of Chemistry, Imo State University Owerri, P. M. B 2000, Imo State, Nigeria.

\begin{abstract}
Concentrations and profiles of 13 polycyclic aromatic hydrocarbons were determined in popular known commercial soft drinks sold in different cities (Aba, Abakiliki, Enugu, Onitsha, Owerri, and Porthacourt) in Nigeria using Hexane for Extraction and gas chromatography equipped with flame ionization detector for quantitative analysis. Physiochemical parameters such as $p H$ was determined as a measure to assess the acidic strength of these drinks, the result obtained revealed the softdrink samples to be acidic with pH values of 2.40 in Onitsha to 2.48 in Abakiliki. Concentrations of the 13 Polycyclic aromatic hydrocarbons (PAHs) in these drinks ranged between 0.76- 31.26, 0.92-38.11, 9.82-14.54, 0.05-28.10, 0.045- 28.29, 9.63$21.49 \mathrm{mg} / \mathrm{mL}$ for Aba, Abakiliki, Enugu, Onitsha, Owerri and Porthacourt respectively. The polycyclic aromatic hydrocarbon profiles indicate the dominance of four and five rings PAHs in these drinks.. The study further accessed the effect of the $\mathrm{pH}$ values for soft drinks samples and the result obtained revealed that acidic pH of the softdrink samples increased the levels of PAHs. Six (6) out of eight (8) carcinogenic polycyclic Aromatic hydrocarbon as classified by the European Food Safety Authority (EFSA) was present in these drinks with concentration ranged from nd-28.29, nd-0.16, nd-11.85, nd-26.62 nd-13.19, 19.93-31.96, for benzo(a)anthracene, chrysene, benzo(a)pyrene, benzo(b)fluoranthrene, dibenz(a_h)anthracene, benzo(g_h_i)perylene respectively. With the exception of dibenzi( $\left.a \_h\right)$ anthrancene, benzo(a)pyrene and chrysene, the concentration values for the carcinogenic PAHs were higher than the maximum limits of 22.10 set by USEPA for water in highly industrialized area in Nigeria. The carcinogenic risk assessment code(CRAC) was accessed in these drinks, based on the tenets of CRAC benzo( $\left.g \_h \_i\right) p e r y l e n e$ was of high risk in soft drink samples purchased from Abakilikiwhich show that people living is such city who consumes this product on daily basis would be exposed to high risk of cancer.
\end{abstract}

Keywords: Polycyclic aromatic hydrocarbons (PAHs), Soft drinks, Beverages, Carcinogenic, cancer, GCFID and Nigeria.

\section{INTRODUCTION}

Polycyclic aromatic hydrocarbon (PAHs) represent a class of organic compounds with carbon and hydrogen structure, having 2 or more fussed ring. ${ }^{1,2}$ recently the environmental protection agency (USEPA) included sixteen of these PAHs compounds in its list of persistent organic Pollutants (POPs). ${ }^{3,4} \mathrm{PAHs}$ compounds are of public interest because it has a unique characteristic of being carcinogenic, mutagenic and tetratogenic ${ }^{5}$ and to this effect contributes to $3.1 \times 10^{-5}$ incremental life time of cancer risk which is major cause to the increased cancer death in Nigeria. The most widely known carcinogenic PAHs is Benzo(a)Pyrene which is considered as a suitable biomarker for it's occurrence in food and other environmental samples. ${ }^{6}$ But recently, the European Food Safety Authority (EFSA) suggest that benzo(a) pyrene alone should not be the most suitable biomarker of carcinogenic PAHs but rather a total number of 8 heavy molecular weight PAHs namely;benzo(a)anthracene, chrysene, benzo(a)pyrene, benzo(b)fluoranthrene, benzo(k)fluoranthrene, $\operatorname{dibenz}(\mathrm{a}, \mathrm{h})$ anthracene, benzo(g,h,i) perelyne, and indeno(1,2,3-cd) pyrene was considered as a more suitable indicator for its occurrence and effect of PAH in food. ${ }^{7,8}$ 
Globally the estimated average intake of PAHs ranged from 0.02 to $3.6 \mu \mathrm{g} / \mathrm{per}$ day/ per person while in Nigeria ranged from $6.0 \mu \mathrm{g} /$ per day/per person. ${ }^{[9]}$ Besides $2-12 \%$ inhalation exposures to PAHs, diet contributes $88-98 \%$ of PAHs exposure especially in the case of non-smoking population. ${ }^{[10]}$ soft drinks may contain large deposits of PAHs incurred through various stages of production such as boiling, heating given that levels of PAHs concentrations are highly temperature dependent. ${ }^{[11]}$ These compounds can also transported through masses of air and soil into water used for industrial production of soft drinks. ${ }^{[12-14]}$ The use of plastic containers for caning also constitute a major source of PAHs deposit or formation in these drinks. ${ }^{[15]}$

Highly industrialized or densely populated areas like Aba, Abakiliki, Enugu Onitsha, Owerri and Porthacourt in Nigeria is often associated with vast introduction of PAHs this is as a result of their high level of anthropogenic activities such as increased heating and boiling, expels from heavy power or gas plant, exhaust of generators, pasteurizing, smoking, urban surface run of from roads and fields, waste incineration and most importantly through emissions from motor vehicles, and other industrial processes. ${ }^{[16][17]}$

As a general rule the lower PAHs which contains not more than four (4) tends to be more soluble, volatile and relatively mobile in the environment, ${ }^{[18-20]}$ while heavy PAHs which are compounds with 5 or more aromatic rings are considered toxic and stable ${ }^{[21]}$ to this effect PAHs differ in their physiochemical characteristics and ecotoxicologicaleffect on human body and its environment.

Recent studiesdone by Chukwujinduet al., 2015revealed the presence 16 PAH spresentin 20 samples of commercial brands of tea, coffee, cocoa based food drinks sold in Delta state (Nigeria). ${ }^{[22]}$ Experiments from Olufumilayo et al., 2018also revealed a total of $11 \mathrm{PAHs}$ in water samples from Atlas cove Lagos, Nigeria ranged from 46-507 $\mu \mathrm{g} / \mathrm{L}$. ${ }^{[23]}$

To the best of our knowledge there is no or inadequate data or reports of PAHs deposit in soft drinks and dietary exposure through soft drinks is more dangerous than exposure through other routes this is because, to the exception to water, soft drinks is largest consumed beverage, it's consumption was rated at $159.85 \mathrm{~g} / \mathrm{person} /$ day in $2007 .{ }^{[24]}$ Therefore it is of utmost importance to carry out this research using a more sensitive and selective analytical method, although many analytical techniques has been widely used lately in determining these PAHs in beverages, and among the few considered were HPLC-Fluorescence ${ }^{[25]}$ and GC/MS, ${ }^{[26]}$ But GC-FID due to it's exceptional recovery during routine evaluation of PAHs in soft drinks is considered. ${ }^{[27]}$ The result obtained from this research will be of great importance to future researchers, soft drinks manufacturers and other agencies in Nigeria like IARC, NAFDAC, UNEP, EPA by providing them with the required information given a more scientific proven advice and recommendation on the consumption of soft drink contaminated with PAHs thereby helping in solving problems of nutrition and health.

\section{MATERials AND METHODS}

The concentrations of 13 individual PAHs were measured in samples of commercially sold brand of soft drink samples. Sample extraction was done at chemistry Laboratory Imo State University while GC-FID quantitative analysis was done at Springboard laboratory opposite i7 udoka housing estate Awka, Anambra State.

\subsection{Materials}

Seperatory funnel, Whatman filter paper, Spatula, Weighing balance, n-Hexane $\left(\mathrm{C}_{6} \mathrm{H}_{14}\right)$, Sodium chloride $(\mathrm{NaCl})$, Sodium Hydroxide $(\mathrm{NaOH})$, Distilled water, Buffer 7 and buffer 4 Tablet, Glass beaker (0-500) Ml, Conical flask (0-500) mL, $250 \mathrm{~mL}$ Glass measuring cylinder, Volumetric flask, Universal bottles, Oven, dessicator, Anhydrous sodium sulphate(NaSO4),Florisil(Magnesium silicate), glass wool, Pastuerpippette, Stop clock, pH meter (JENWAY 3510), AID Agilent technology 200 GC -FID Spectroscopy.

\subsection{Sample Collection}

Six (6) plastics of commercially sold soft drinks were purchased from six (6) different cities namely; Aba, Enugu, Abakiliki, Port Harcourt, Onitsha and Owerri in Nigeria during the month of JulyOctober 2019. The purchased samples were properly stored at room temperature $\left(25^{\circ} \mathrm{C}\right)$ in a cool dry place. All necessary chemicals and reagents used were of high analytical grade and were purchased from chemi science lab Owerri, Nigeria. 


\section{3. pH}

Jenway $3510 \mathrm{pH}$ meter was used to measure the $\mathrm{pH}$ of the soft drink samples. The $\mathrm{pH}$ meter was calibrated using buffer 4 and buffer 7 by dissolving one capsule each in $100 \mathrm{~mL}$ of distilled water, then the electrode was introduced into each of the soft drink samples until the reading was stabilized, measurements were then taken.

\subsection{Sample Extraction from Soft Drink Samples}

Soft drinks samples were properly agitated and filtered through a filter paper, $\mathrm{pH}$ of the samples were checked and it was found to be acidic, $\mathrm{pH}$ of all the samples were adjusted to neutral by using $1 \mathrm{~mL}$ each of $0.1 \mathrm{M} \mathrm{NaOH}$. After filtration $25 \mathrm{~mL}$ of each Samples were taken into a seperatory funnel and $5 \mathrm{~mL}$ of saturated $\mathrm{NaCl}$ solution was added, $10 \mathrm{~mL}$ of $\mathrm{n}$-Hexane solvent was added to extract the samples and the mixture was shaken vigorously for about 2-3minute, after proper agitation the mixture was allowed to settle, the layers were separated. The soft drinks solution formed at the upper layer while the extracted solvent were seen at lower layer, the cork of the separating funnel was opened to gradually decant the extracted solvent which was then taken for florisil clean-up.

\subsection{Florisil Clean of Extracted Samples}

Florisil (Magnesium silicate ) was heated in an oven at $130^{\circ} \mathrm{C}$ overnight (ca.15h) and transferred to a $250 \mathrm{ml}$ size beaker and placed in a desicator, anhydrous $\mathrm{NaSO}_{4}$ was added to $1.0 \mathrm{~g}$ of activated flosiril (magnesium silicate) $(60-100 \mathrm{~nm}$ mesh) on an $8 \mathrm{ml}$ column plugged with glass wool. Packed column filled with $5 \mathrm{ml} \mathrm{n}-$ Hexane was used for conditioning. Stopcock was opened to allow $\mathrm{n}-$ Hexane run out until it reached the top of sodium sulphate into a receiving vessel whilst top of the column was tapped gently the till the florisil settled well in the column. The Extract was transferred on to the column with disposable Pasteur pipette from an evaporating flaskeach evaporating flask was rinsed twice with $1 \mathrm{ml}$ portions of $\mathrm{n}-$ hexane and added to the column. Eluate was collected into an evaporating flask and rotary evaporated to dryness, Dry eluate was dissolved in $1 \mathrm{ml} \mathrm{n}$ - hexane for PAH Chromatographic analysis.

\subsection{GC-FID Analysis}

The quantitative analysis for PAHs in the extracted solvent were done using AID Agilent Technology 200 GC-FID with A RESTEK 15METER MXT-1 column and the LC is usually estimated by integrating the areas of the resolved and unresolved, Helium was the carrier gas and a pressure 5 PSI was used for column elution. Sample injection was carried out using a syringe. The GC oven temperature was programmed first from $50^{\circ} \mathrm{C}$ (hold $1 \mathrm{~min}$ ), ramped at $10^{\circ} \mathrm{C}$ to a final temperature of $110^{\circ} \mathrm{C}(1 \mathrm{~min})$.

\section{Results}

Table 1.0.pH of the tested soft drinks

\begin{tabular}{|c|c|}
\hline Locations & pH \\
\hline Aba & $2.42 \pm 0.12$ \\
\hline Abakiliki & $2.48 \pm 0.10$ \\
\hline Enugu & $2.46 \pm 0.10$ \\
\hline Porthacourt & $2.43 \pm 0.09$ \\
\hline Onitsha & $2.40 \pm 0.10$ \\
\hline Owerri & $2.44 \pm 0.11$ \\
\hline
\end{tabular}

Table1.1. Showing percentage concentrations of PAHs in the soft drinks samples from their respective location.

\begin{tabular}{|c|c|c|c|c|c|c|}
\hline PAHs COMPOUDS & A\% of AB & A\% of AK & A\% of EN & A\% of ON & A\% of OW & A\% of PH \\
\hline Acenapthene & 0.76 & 0.92 & ND & ND & ND & ND \\
\hline Fluorene & 34.20 & 3.74 & 16.4 & 11.88 & 11.99 & 16.11 \\
\hline Anthracene & 31.26 & 38.11 & 14.54 & 13.19 & 13.30 & 14.28 \\
\hline Fluoranthene & ND & ND & 9.82 & ND & ND & 9.63 \\
\hline Benzo(a)pyrene & 5.78 & 7.21 & 11.85 & ND & 0.045 & 11.69 \\
\hline Benzo(g_h_i) perylene & 26.24 & 31.96 & 21.92 & 19.93 & 20.13 & 21.49 \\
\hline Dibenzl(a_h) anthracene & ND & ND & 13.19 & 0.05 & ND & 12.93 \\
\hline 1_2 Benzathracene & 0.15 & ND & ND & 28.10 & 28.29 & ND \\
\hline
\end{tabular}


Assessment of Polycyclic Aromatic Hydrocarbons in Popularly Known Commercial Brands of Soft drinks Sold in different Cities in Nigeria

\begin{tabular}{|c|c|c|c|c|c|c|}
\hline \multicolumn{7}{|c|}{} \\
\hline Benzo(k) fluoranthene & 0.10 & ND & ND & ND & ND & ND \\
\hline Pyrene & 14.88 & 18.04 & ND & 0.34 & 0.22 & ND \\
\hline Chrysene & ND & ND & ND & ND & 0.16 & ND \\
\hline Benzo(b) fluoranthene & ND & ND & ND & 26.62 & 25.87 & ND \\
\hline Acenapthylene & ND & ND & 12.31 & ND & ND & 13.96 \\
\hline
\end{tabular}

$N D=$ Not detected, $A \%=$ percentage concentrations of the individual PAHs compounds present in the soft drink samples, $A B=A b a, A K=$ Abakiliki, EN=Enugu, ON=Onitsha, OW=Owerri, $P H=$ Porthacourt.

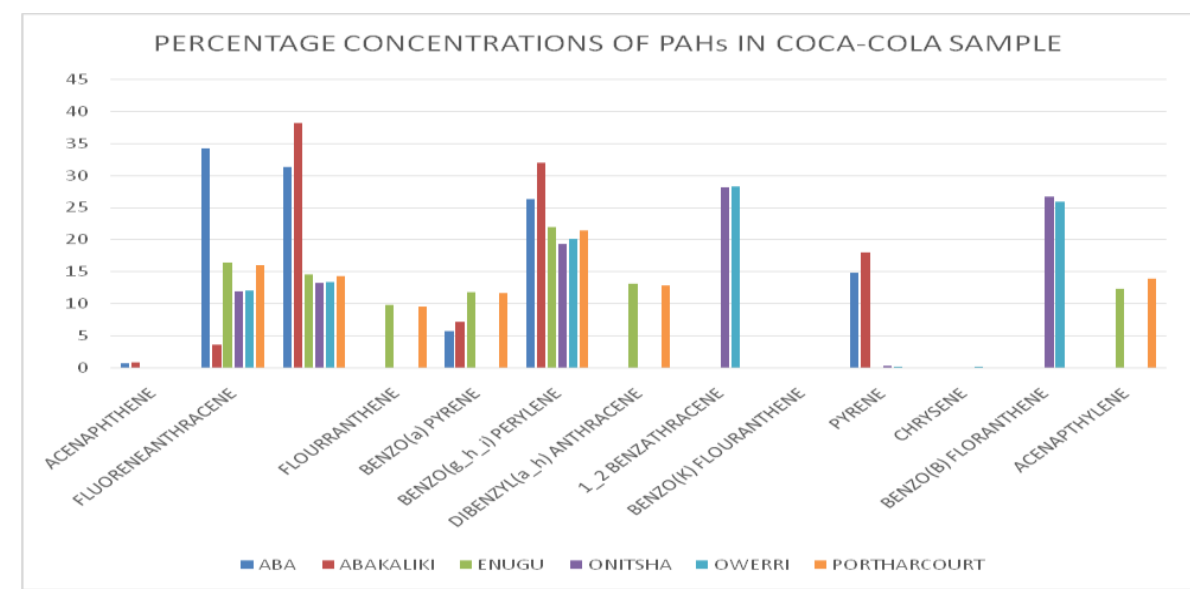

Fig1.0. showing the percentage concentrations of PAHs in soft drink samples purchased from each locations

A Graphical Representation of Percentage Concentration of Pahs Against pH

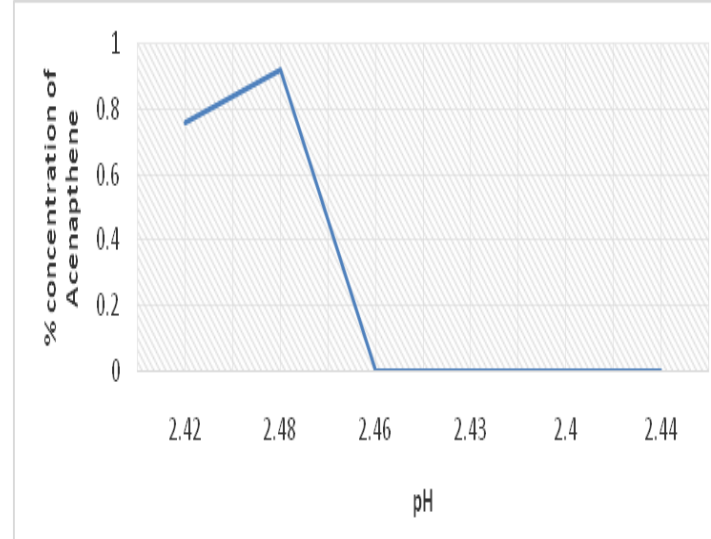

Fig 1.1. Graphical representation of acenapthene percentage concentrations against $\mathrm{pH}$

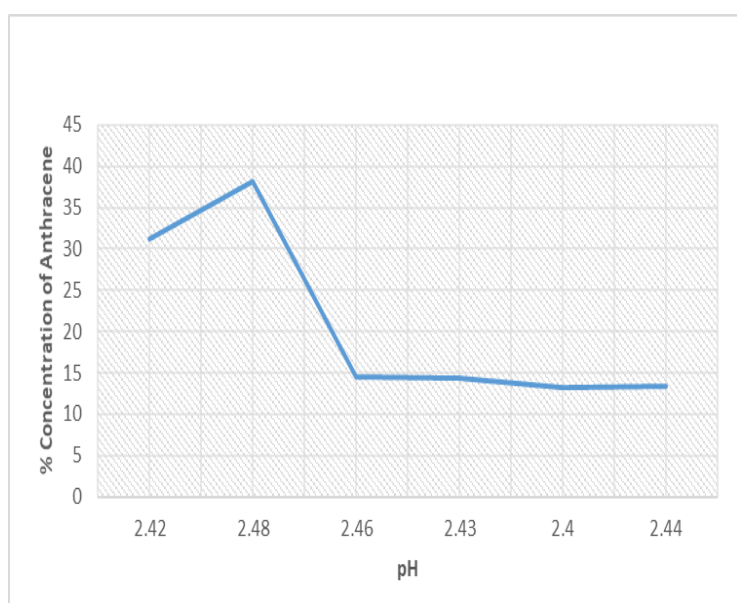

Fig1.3. Graphical representation of anthracene percentage concentrations against $\mathrm{pH}$

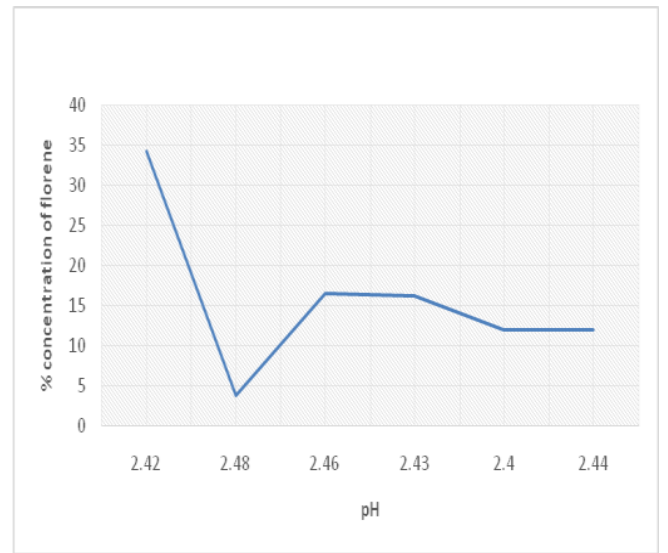

Fig 1.2. Graphical representation of fluorene percentage concentrations against $\mathrm{pH}$

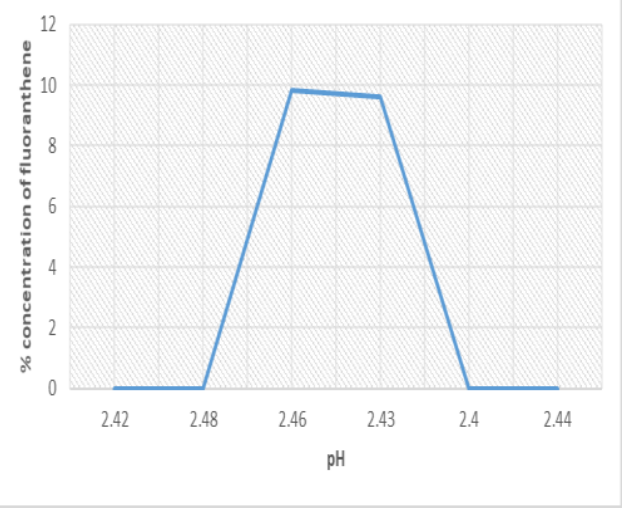

Fig1.4. Graphical representation of fluoranthene percentage concentrations against $\mathrm{pH}$ 


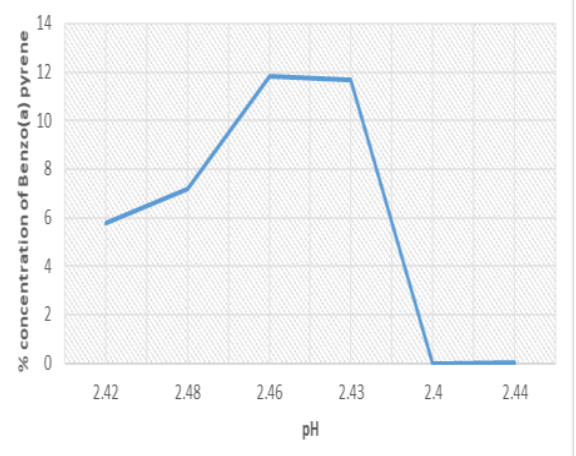

Fig1.5. Graphical representation of benzo(a)pyrene percentage concentrations against $\mathrm{pH}$

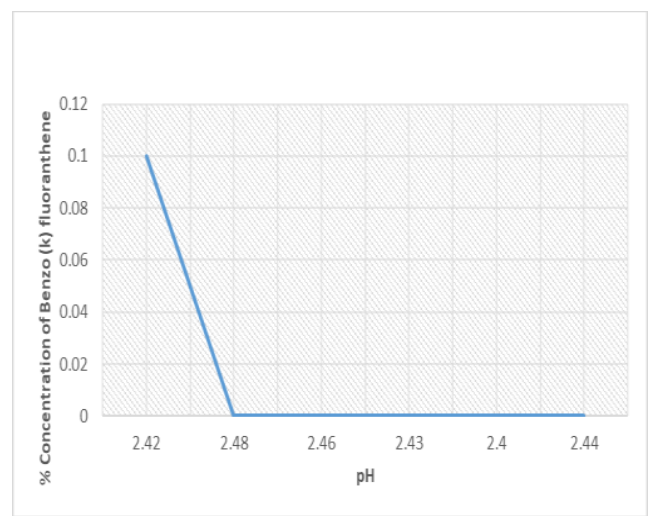

Fig. 1.7. Graphical representation of bezo( $k)$ fluoranthene percentage concentrations against $\mathrm{pH}$

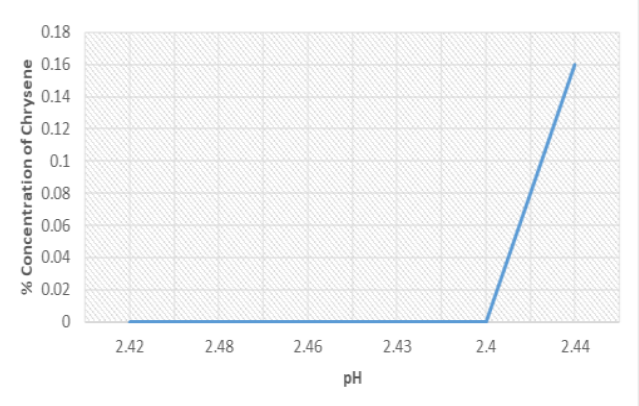

Fig1.9.Graphical representation of chrysene percentage concentrations against $\mathrm{pH}$

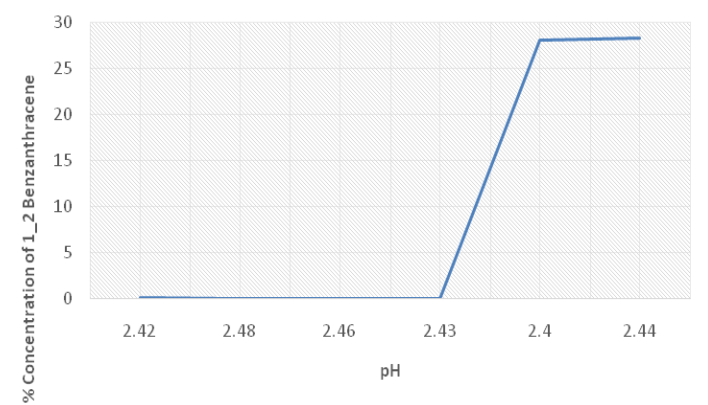

Fig1.11. Graphical representation of 1_2 benzan thracene percentage concentration against $\mathrm{pH}$

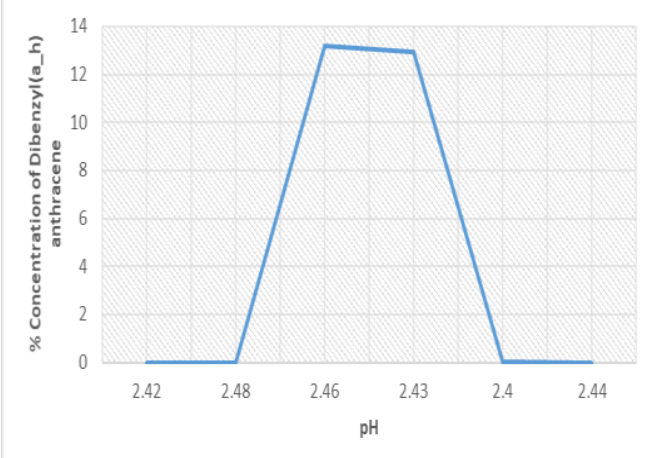

Fig 1.6. Graphical representation of dibezyl ( $\left.a \_h\right)$ anthracene percentage concentrations against $\mathrm{pH}$

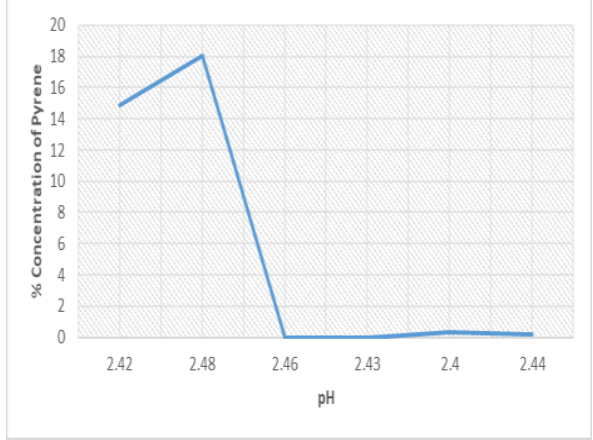

Fig1.8. Graphical representation of pyrene percentage concentrations against $\mathrm{pH}$

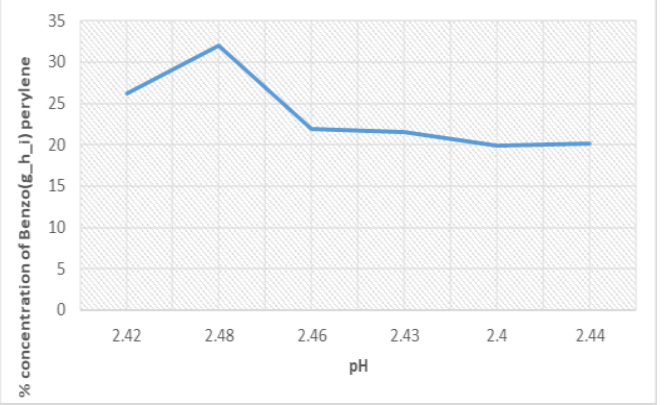

Fig1.10. Graphical representation of benzo(g_h_I) perylene percentage concentrations against $\mathrm{pH}$

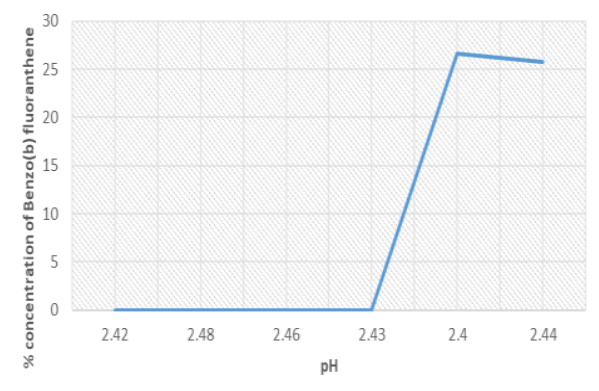

Fig 1.12. Graphical representation of benzo $(b)$ fluoranthene percentage concentrations against $\mathrm{pH}$ 


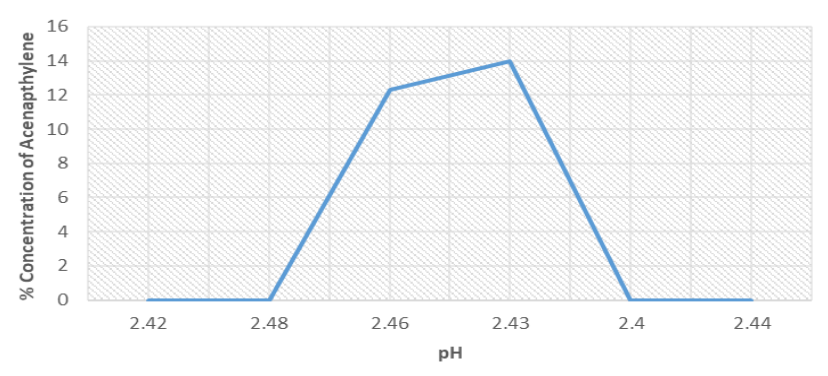

Fig 1.13. Graphical representation of acenapthylene percentage concentrations against pH

Table1.2. Shows the sum of Carcinogenicity and Non-Carcinogenicity.

\begin{tabular}{|c|c|c|c|}
\hline Carcinogenic PAHs & $\begin{array}{c}\text { Sum of carcinogenic } \\
\text { PAHs }\end{array}$ & Non carcinogenic PAHs & $\begin{array}{c}\text { Sum of non } \\
\text { carcinogenic PAHs }\end{array}$ \\
\hline 1_2 Benzanthracene & 56.54 & Acenahthene & 1.68 \\
\hline Chrysene & 0.16 & Fluorene & 94.32 \\
\hline Benzo(a)pyrene & 36.58 & Anthracene & 124.68 \\
\hline Benzo(b) fluoranthene & 52.49 & Fluoranthene & 19.45 \\
\hline Benzo(k) fluoranthene & 0.10 & Pyrene & 33.48 \\
\hline Dibenzl(a_h) anthracene & 26.17 & Acenapthylene & 26.27 \\
\hline Benzo(g_h_i) perylene & 141.67 & & $\sum$ nc $=299.88$ \\
\hline
\end{tabular}

Carcinogenicity ratio $=1.0, \%$ Carcinogenicity $=51 \%, \%$ Non Carcinogenicity $=49 \%$

Table1.3. Carcinogenic Risk assessment code (CRAC) for the soft drinks in each state

\begin{tabular}{|l|c|c|c|c|c|c|}
\hline Carcinogenic PAHs & AB & AK & EN & ON & OW & PH \\
\hline 1_2 Benzathracene & 0.13 & 0 & 0 & 28.10 & 28.29 & 0 \\
\hline Chrysene & 0 & 0 & 0 & 0 & 0.16 & 0 \\
\hline Benzo(a)pyrene & 5.09 & 7.21 & 11.85 & 0 & 0.045 & 11.69 \\
\hline Benzo(b) fluoranthene & 0 & 0 & 0 & 26.62 & 25.87 & 0 \\
\hline Benzo(k) fluoranthene & 0.08 & 0 & 0 & 0 & 0 & 0 \\
\hline Dibenzyl(a_h) anthracene & 0 & 0 & 13.19 & 0.05 & 0 & 12.93 \\
\hline Benzo(g_h_i) perylene & 23.14 & 31.96 & 21.92 & 19.93 & 20.13 & 21.49 \\
\hline
\end{tabular}

\section{DisCUSSIONS}

\section{1. pH}

$\mathrm{pH}$ is an indication of the acidic strength of the nutrient solutions in the soft drink samples. ${ }^{[28]}$ From Table 1.0 the $\mathrm{pH}$ values of the soft drinks samples ranged from 2.40 in Onitsha to 2.48 in Abakiliki with an average mean $\mathrm{pH}$ of 2.44 which is in correlation with mean $\mathrm{pH}$ values of 2.46and 2.45 carried by Hara et al $^{[29]}$ and Lussi et al. ${ }^{[30]}$ thus the samples were highly acidic (i.e $\left.\mathrm{pH}<4\right)$. The acidity of the soft drink samples could be deduced as result of the presence of Phosphoric acid $\left(\mathrm{H}_{3} \mathrm{PO}_{4}\right)$ added as one of the major components to balance the sweetness of sugar present and also with the carbonic acid $\left(\mathrm{HCO}_{3}\right)$ formed due to $\mathrm{CO}_{2}$ dissociated in water $\left(\mathrm{H}_{2} \mathrm{O}\right)^{\cdot[31]}$

Basically from fig 1.1-1.13 the graphical representation of the percentage concentration against $\mathrm{pH}$ it can be deduced that the $\mathrm{pH}$ of the soft drinks samples increases as PAHs concentrations increases and vice versa. Aba with higher acidic $\mathrm{pH}$ of 2.42 has a higher number of PAHs deposit than the remaining samples, works from Efe et Al reveals that soils or water bodies within such industrialized area is majorly acidic owing to their improper emision from hydrocarbon production or sources ${ }^{[32]}$ and the results revealed from studies carried out on formation of PAHs in water and sediment by (Abiodun, et al) ${ }^{[33]}$ proves that acidic $\mathrm{pH}$ greatly influences PAHs deposition or formation.

\subsection{Percentage Concentrations of PAHs}

The result obtained for the percentage concentrations of PAHs in the soft drink samples from each state is represented in table 1.2 as shown above. A total number of 13 PAHs was observed in these soft drinks with percentage concentrations ranged between 0.76- 31.26 \%, 0.92-38.11\%, 9.82-14.54 
$\%, 0.05-28.10 \%, 0.045-28.29 \%, 9.63-21.49 \%$ for Aba, Abakiliki, Enugu, Onitsha, Owerri and Porthacourtre spectively. Acenapthene was present in samples from Aba and Abakiliki respectively with concentrations ranged between $0.76-0.92 \mathrm{mg} / \mathrm{mL}$, Flourene, anthraceneand Benzo(g_h_i)) perylene was detected in all the samples with percentage concentrations ranged between 3.74-34.20, 13.19-38.11 and 19.93-31.96 respectively, works from Obini et al ${ }^{[15]}$ reveals that anthracenedeposit in soil samples at auto mechanic village Abakiliki is due tomajor use of plastic containers and other petroluem products. Fluoranthene was present in samples from Enugu and Porthacourt. Benzo(a) pyrene was detected in all samples with the exception to Onitsha at percentage concentration ranged between $0.045-11.85 \mathrm{mg} / \mathrm{mL}$. The polycyclic aromatic hydrocarbon profiles indicate the dominance of four and five rings PAHs in these drinks, The lighter PAH were about9which includes namely; Acenahthene, acenapthylene, Fluorene, anthracene, Dibenzl (a_h) anthracene, chrysene, pyrene, fluoranthene, could be associated with PAHs deposits from while the heavy PAHs where about 4 namely; Benzo(a)pyrene, Benzo(k) fluoranthene, Benzo(g_h_i)perylene, Dibenzyl(a_h) anthracene.

From Table 1.2 Six(6) carcinogenic PAHs namely: Benzo(a) anthracene, chrysene, Benzo(a) pyrenebenzo (b) fluoranthene, dibenzy(a_h) anthracene, Benzo (g_h_l) perylene were identified in these sample with \% concentration values ranged between nd-28.29, nd-0.16, nd-11.85, nd- 26.62 nd13.19, 19.93-31.96, respectively. fall within the category of PAHs with the highest risk especially at prolonged exposure as reported by AATSDR[34]. With the exception of dibenzi (a_h) anthrancene, benzo(a)pyrene and chrysene, the concentration values for the carcinogenic PAHs were higher than the maximum limits of 22.10 set by USEPA for water in highly industrialized area in Nigeria. ${ }^{[35]}$

\subsection{Carcinogenic Risk Assessment Code (CRAC) in the Soft Drink Samples}

The model assumes that the most bioavailable fraction in the soft drink samples are likely to be absorbed in the body system hence; it is considered carcinogenic to humans. Therefore in the basic tenets of CRAC five categories are employed in the interpretation of the model result obtained in table 3.12 as follows; No Risk CRAC > 1, low Risk $1<$ CRAC > 10, Medium Risk $11<$ CRAC > 30, High Risk $30<$ CRAC $>50$, Very high Risk CRAC $<50$. This is to show that in the soft drinks samples purchased from Aba all PAHs detected were of low Risk except Benzo (g_h_i) perylene which was of medium risk, same also applies to Abakiliki but Benzo (g_h_i) perylene was of a very high Risk. In considering soft drinks samples from Enugu Benzo (a) pyrene, benzo(g_h_i) perylene and Dibenzyl(a_h) anthracene were all of medium risk. Onitsha had PAHs detected to be of medium risk too same applies to Owerri and Porthcourt respectively.Benzo (g_h_i) perylene which is known to be carcinogenic was present in all soft drinks samples analyzed in this study (table 1.1) considering the tenets of CRAC in (table 1.3) Benzo ( $\left.g \_h \_i\right)$ was of high or medium risk and it's contribution to carcinogenicity was significant. Therefore it is suggested that most people living within these cities most especially Abakiliki would be exposed to high risk of cancer. The deposition of these carcinogenic PAHs into these drinks could be attributed to ability of PAHs in the environment to have leached into water used industrially for production or would be as a result of various Anthropogenic activities in these cities such as emissions from, petroleum, coal heavy gas plants, automobile, improper waste incineration emissions from exhaust generators which is a common practice these cities. ${ }^{[36]}$ Thus their accumulative effect over time through soft drinks could be detrimental to human health and may cause some of life threatening diseases such as cancer associated with presence of PAHs. ${ }^{[37]}$

\section{CONCLUSION}

The results revealed soft drinks contained significant amounts of six carcinogenic PAHs namely: benzo(a) anthracene Chrysene benzo (a) pyrenebenzo (b) fluoranthenedibenzy (a_h)anthracene and benzo(g_h_l) perylene which could pose a serious hazard to consumers who take these products on a regular basis. The PAH profiles indicate the dominance of 4-5-ring PAHs. Considering the carcinogenic Risk assessment code (CRAC) benzo(g_h_i) perylene was of a high Risk in soft drink samples from Abakiliki, Thus this study stressed the need to alleviate anthropogenic activities carried by man in these cities and also ensure good manufacturing practice among soft drinks manufacturers and also relevant agencies such as Consumers Protect Rights, National Agency for Food, Drug Administration and Control (NAFDAC) and Standard Organization of Nigeria (SON) should enforce strict compliance to the desired levels of these contaminants in beverages and Hazard Analysis Critical Control Point (HACCP) in all beverage production. 


\section{REFERENCES}

[1] Qui C.Y., Beng B., Cheng S.Q., Xia Y.Y and Yu B.Y (2013).The effect of occupational exposure to benzo(a)pyrene on neurobehavioral function in coke oven workers. American journal of industrial medicine 56, 347-355.

[2] Li G. (2016). Concentrations dietary exposure and health risk estimation of polycyclic aromatic hydrocarbons (PAHs) in youtiao, a Chinese traditional fried food. Food control, 59(3):328-336.

[3] US EPA. Priority Pollutants List. http://www.epa.gov/sites/production/files/201509/documents/priority pollutant-list-epa.pdf. Access: December 5th, 2019.

[4] Samburova, V.; Zielinska, B.; Khlystov, A. D. (2017). 16 Polycyclic Aromatic Hydrocarbons Represent. Toxics, 5, 29-33.

[5] Fagbote EO and Olanipekun EO (2010), Levels of polycyclic aromatic hydrocarbons and polychlorinated biphenyls in sediment of bitumen deposit impacted area, Int. J. Environ. Sci. Tech. 7:56s1-570.

[6] Qiao J., Zhang C.D., Luo S.M. and Chen W. (2014), Bioremediation Of highly contaminated oilfield soil: bioaugmentation for enhancing aromatic compounds removal, Frontiers of Environmental Science \& Engineering, 8, 293-304.

[7] Benson N.U., Fred-Ahmadu O.Y., Olugbuyiro J.A.O.(2017) levels of Polycyclic aromatic hydrocarbon (PAH4) in some selected popular tea brands in Nigeria. $15^{\text {th }}$ international conference on environmental science and technology pp. 1-7.

[8] Nuccon M.S. and Schantz M.S (2013). Determination of selected oxygenated polycyclic aromatic hydrocarbons (oxy-PAHs) I diesel and air particulate matter standard reference materials (SRMs) Anal bional chem.405:5583-5593.

[9] Diggs D.I., Hunderson A.C., Harris K.Y. and Ramesh A.(2011) Polycyclic aromatic hydrocarbon and digestive tract cancers. A perspective Journal of environmental science and health part C, 29 (4): 324-357.

[10] Essumang D.K., Dodoo. K and Adeji J.K (2013). Effect of smoke generation sources and smoke curing duration on the levels of PAHs in different suited of fish. Food and chemical Toxicology, 58(6): 86-94.

[11] Visciano, P.; Perugini, M.; Amorena, M.; Janineri, A.( 2006) Polycyclic aromatic hydrocarbons in fresh and old smoked Atlantic salmon fillet. Journal of Food Protection 69, 1134-1138.

[12] Orechio S., Ciotti V.P and Culota S. (2009) Polycyclic aromatic hydrocarbon (PAHs) in coffee brew samples; analytical methods by GC-MS,profile levels and sources. Food and chemical toxicology, 47(4): 819-826.

[13] Poster, D.L.; Shantz, L.C.; Wise, S.A. (2006) Analysis of polycyclic aromatic hydrocarbons (PAHs) in environmental samples: a critical review of gas chromatographic (GC) methods. Anal. Bioanal. Chem., 386, 859.

[14] Wenzl, T.; Simon, R.; Kleiner, J.; Anklam, E.(2006) Analytical methods for polycyclic aromatic hydrocarbons (PAHs) in food and the environment needed for new food legislation in the European Union.Trends Anal. Chem., 25, 716-725.

[15] Obini U., and Okafor C.O.,(2013) Determination of levels of PAHs in soil contamination with spent motor engine oil in Abakiliki, auto mechanic village, journal of applied science and environmental management 17(2)169-175.

[16] Oyo-ita O.E., Oyo-ita I.O and Ugim S.U (2011). Sources and determination of Polyclic Aromatic hydrocarbons in post flooded soil near afam power station, south east Niger Delta, Nigeria. Journal of soil science and environment management, 2(3): 329 - 340.

[17] Nwachi, E.O., Chuku, LC; Ighoavwogan, E (2016). Polycyclic aromatic hydrocarbons and selected heavy metals in some oil polluted sites in Delta state Nigeria JEP. 7(12): 1389-1410.

[18] Ogali, RE., Osuji, LC. And Ayodele, O (2007). Acute Toxicity of the water soluble fraction of spent lubricating oil on the African catishclariasgariepinus.Chem.Biodiv. 4,2755-2765

[19] Arababi M., Nasseri S. and Anyakora C. (2009), Biodegradation of Polycyclic Aromatic Hydrocarbon in Petroleum contaminated soils, Iranian Journal of Chemistry and Chemical Engineering, 28, 53-59.

[20] Olatunji O.S., Fatoki O.S., Opeolu B.O. and Ximba B.J. (2014), Determination of Polycyclic Aromatic Hydrocarbon (PAHs) in processed meat products using gas chromatography-flame ionization detector, Journal of Food Chemistry, 156, 296- 300.

[21] Bolaños, P.P.; Frenich, A.G. and Vidal, J.L.M. (2010) Polycyclic aromatic hydrocarbons in food and beverages. Analytical methods and Trends. J. Chromatogr. A., 1217, 6303-6326.

[22] Engwa A.G., Ihekwoba C.J. and Illo U.C 2015). Determination of soft drink constituent and contaminant by some heavy metals in Nigeria. J. Toxicology, 2:384-390. 
[23] Chukwujindu M.A., Iwuegbe H., Agadaga F. and Bassey M. (2015).concentrations and profiles of polycyclic aromatic hydrocarbons in some selected brands of tea, coffee and cocoa-based food drinks in Nigeria. International Journal of food, 18(18): 2124-2133.

[24] Engwa A.G., Ihekwoba C.J., IlloU.C.(2015). Determination of soft drink constituent and contaminant by some heavy metals in Nigeria. J. Toxicology, 2:384-390.

[25] Ibadov N.A., Huseynov V.I., Suleymanov B.A. (2004) Determination of Polynuclear Aromatic Hydrocarbons By High Performance Liquid Chromatography, Journal of the Chemical Problems, №2, pp.40-48.

[26] Reddy Christopher M. And Quinn James G. (1999), Marine Pollution Bulletin, Vol. 38, No. 2, pp. 126$135,1999$.

[27] Iwegbue C.M.A. Obi, G., TesiG.O.Bassey, F.I.Overah, L.C Concentrations of polycyclic aromatic hydrocarbons in some commercial brands of candies and chocolates in Nigeria. Quality assurance and safety of crop science, 7(5):461- 476.

[28] SeowWk, Thong KM.(2005). Erosive effects of common beverages on extracted premolar teeth. Dent $\mathrm{j}$ 50(3):173-178.

[29] Hara A.T. and Zero D.T. (2008). Analysis of erosive potential of calcium containing acidic beverage, Eur J. Oral Sci. 116(1): $60-65$.

[30] Lussi A., Merget B., Shellis R.P., Wang X.(2012). Analysis of the erosive effect of different dietary substance and medications. Br Nutr. 107(2): 252 - 262.

[31] Taji S. Seow WK., (2010). A literature review of dental erosion in children. Australia Dent. J. 55(4):358367.

[32] Efe S.I. and MogborukorJ.O.A (2012). Acid rain in Niger Delta region: Implication on water resources quality and crisis. AFRREV STECH. 1(1):17-46.

[33] AbiodunO.A.OmobolaO.O, and Anthony I.O. (2018). Analytical methods for polycyclic aromatic hydrocarbons and their Global Trend of Distribution in water and sediment: A review. http://dx.doi.org/10.5772/intechopen.71163. 394-428.

[34] ATSDR (2007) Agency for Toxic Substances and Disease Kissane, K (2009). Fire power Registry.Toxicological Profile for Lead, U.S. Department of Health and Human Services: Atlanta, U.S.A.

[35] Ana, Gree, Srdhar MKC, Emerole G.O. (2011). Contamination of surface waters by PAHs in two Nigeria coastal communities. Journal of Environmental Health Research 11(2) 77-86.

[36] Emerole G.O., and Sridhar MKC.(2012) polycyclic aromatic hydrocarbon burden in ambient air in selected Niger Delta communities in Nigeria Journal of the Air and waste Management Association 62(1):18-25.

[37] Orechio S., Ciotti V.P and Culota S. (2009) Polycyclic aromatic hydrocarbon (PAHs) in coffee brew samples; analytical methods by GC-MS,profile levels and sources. Food and chemical toxicology, 47(4): 819-826.

Citation: Enyoh Christian Ebere, et.al, "Assessment of Polycyclic Aromatic Hydrocarbons in Popularly Known Commercial Brands of Soft drinks Sold in different Cities in Nigeria”, International Journal of Advanced Research in Chemical Science, vol. 6, no. 10, p. 28-36, 2019. DOI: http://dx.doi.org/10.20431/23490403.0610004

Copyright: (C) 2019 Authors. This is an open-access article distributed under the terms of the Creative Commons Attribution License, which permits unrestricted use, distribution, and reproduction in any medium, provided the original author and source are credited. 